\title{
Enzymatic and quantitative variation in European and African populations of Drosophila simulans
}

\author{
P. Hyytia, \\ P. Capy, \\ J. R. David and \\ *R. S. Singh
}

\author{
Laboratoire de Biologie et Génétique Evolutives CNRS, \\ 91190 Gif sur Yvette, France; \\ * Department of Biology, McMaster University, \\ Hamilton, Ontario Canada L8S 4K1.
}

\begin{abstract}
Allozyme polymorphism at 15 loci of $D$. simulans was studied in 7 natural populations from Europe, North and tropical Africa. Morphological traits were studied in nine European and eleven Afrotropical strains.

Within a population, the biochemical polymorphisms of Drosophila simulans and its sibling Drosophila melanogaster are not very different, although $D$. simulans has a lower heterozygosity. Between-populations genetic differentiation is however much lower in $D$. simulans than in $D$. melanogaster. Several loci of $D$. simulans do exhibit latitudinal trends but these are relatively weak.

For morphological traits, both species show an increase of size with latitude, but geographic variation is again less pronounced in $D$. simulans. Both species are native to tropical Africa and have colonised the rest of the world. During this process, $D$. simulans has undergone much less geographic differentiation than has $D$. melanogaster, so that the ecological success of the two species is not correlated with similarities in their genetic properties.
\end{abstract}

\section{INTRODUCTION}

Among about 2500 species known in the drosophilid family (Wheeler, 1981), only 21 have a subcosmopolitan status, in that they exist in at least three non-adjacent biogeographic realms (David and Tsacas, 1981). All these species occupy their present geographic range as a result of involuntary transport by man. Among the 21 species, the sibling $D$. melanogaster and $D$. simulans are especially interesting since they are the only two which possess large populations in both tropical and temperate conditions (David and Tsacas, 1981). Many studies of the ecology, ecophysiology and genetics of these domestic species have attempted to understand their population dynamics, ecology and other reasons of which may underlie their demographic success (e.g., Parsons, 1975; 1980a; 1983; Parsons and Stanley, 1981).

Populations of $D$. melanogaster, are genetically highly differentiated, for chromosomal polymorphism (Ashburner and Lemeunier, 1976; Watanabe and Watanabe, 1977; Voelker et al.,
1978; Stalker, 1980; Knibb et al., 1981), allozyme variation (Kojima et al., 1970; Band, 1975; Mettler et al., 1977; Triantaphyllidis et al., 1980; 1982; Oakeshott et al., 1981 $a, b$; David, 1982; Singh et al., 1982; Capy et al., 1983; Anderson and Oakeshott, 1984), biometrical traits (Teissier, 1956; Tantawy and Mallah, 1960; David et al., 1976; 1977; Capy et al., 1983) and physiological traits (David and Bocquet, 1975; Allemand and David, 1976; David et al., 1977; Cohet et al., 1980; Parsons, $1980 b, c$; Bouletreau-Merle et al., 1982). Several authors argue that this extensive genetic differentiation is one cause of the demographic success of $D$. melanogaster under a variety of ecological conditions.

D. simulans is closely related to $D$. melanogaster and shows comparable ecological success. We might hence expect a comparable genetic differentiation among its populations. However, although $D$. simulans is far less studied it already appears that, for a variety of traits, it is less variable than $D$. melanogaster. For example, natural populations are monomorphic for their chromosome structures (Ashburner and 
Lemeunier, 1976); the species does not exhibit a latitudinal cline for ethanol tolerance (David and Bocquet, 1975); its protein polymorphism, studied with 2-dimensional electrophoresis, is lower than in D. melanogaster (Onishi et al., 1982). Surprisingly few studies have been devoted to allozyme polymorphism in D. simulans (O'Brien and MacIntyre, 1969; Berger, 1970; Triantaphyllidis, 1973; Steiner et al., 1976; Triantaphyllidis et al., 1980; Salam et al., 1981; 1982; Cabrera et al., 1982; Onishi et al., 1982; Anderson and Oakeshott, 1984) and most of these concern temperate populations.

D. melanogaster and D. simulans are now known to be native to tropical Africa (Tsacas and Lachaise, 1974; David and Tsacas, 1981) and in $D$. melanogaster, there is extensive genetic divergence between the ancestral, Afrotropical populations and the European ones. Here we compare the allozyme polymorphism of seven natural populations of $D$. simulans from Europe, North and tropical Africa (mainland and islancis). Differences in metric characters are often easier to detect than are differences in gene frequencies (e.g., Lewontin, 1984) and are generally thought to be more directly subject to natural selection than are allozymes (Kimura, 1983). Our analysis has hence been extended to include morphological comparisons between French and Afrotropical populations of D. simulans and D. melanogaster.

\section{MATERIALS AND METHODS}

Wild living females were used to initiate isofemale lines. Two adult flies were electrophoresed from each line after a few generations (from 1 to 10 ) of laboratory culture. The populations sampled were from Villeurbanne, France (20 lines), Antibes, France (23 lines), Athens, Greece (25 lines), Nasrallah, Tunisia (42 lines), Brazzaville, Congo (39 lines), Mahé, Seychelles islands $(23$ lines $)$ and Tananarive, Madagascar (26 lines).

Methods of starch gel electrophoresis were adapted from Shaw and Prasad (1970) and Ayala et al., (1972), and 15 different gene-enzyme loci were studied in each population. Alleles were characterised by their migration distance on the gel, the most common one receiving the arbitrary value of $1 \cdot 00$. Expected heterozygosity was calculated (assuming Hardy-Weinberg equilibrium) for each locus and populations. Few enzyme loci are mapped in $D$. simulans. However, in all cases, an homology could be established with an already identified locus of $D$. melanogaster and we have used the same nomenclature for describing enzyme systems in eảch species. Moreover, we have also indicated when alleles with identical mobilities were observed in the two species.

Biometrical analysis was performed on 9 French and 11 Afrotropical strains. Each strain was founded by several (in most cases more than 10) females and kept in the laboratory as a mass culture in bottles. Larvae were grown at $25^{\circ} \mathrm{C}$ at low density on a killed yeast medium and for each strain, six different traits were measured on 30 different adults. These traits were fresh adult weight (taken a few hours after emergence), wing and thorax lengths, sternopleural and abdominal chaetae numbers and ovariole number in females (see David, 1979 for more details). Viability and duration of development were also measured for each strain, starting from a sample of 300 eggs (see David et al., 1976, for techniques).

\section{RESULTS}

\section{Allozyme frequencies}

Five of the 15 loci studied: ADH (alcohol dehydrogenase), FU (fumarase), HK-3 (hexokinase 3), ME (malic enzyme) and 6-PGD (6 phosphogluconate dehydrogenase) were monomorphic in all populations.

The most polymorphic loci (table 1) as shown by average expected heterozygosities (table 2 ) are EST-C (esterase-C), EST-6 (esterase 6), ACPH (acid phosphatase), PGM (phospho-glucomutase), XDH (xanthine dehydrogenase), ALDOX (aldehyde oxidase) and HK-1 (hexokinase 1). These results generally confirm what was already found by previous authors with the exception of HK-1 (Kojima et al., 1970; Onishi et al., 1982 and Cabrera et al., 1982) which was previously found to be polymorphic ( 2 alleles) only at low heterozygosity $(0.019)$ in a single Spanish population. ADH is generally monomorphic in $D$. simulans and we failed to find any rare alleles, although such alleles have been reported from other parts of the world: such as Texas (Kojima et al., 1970); Hawaii (Steiner et al., 1976) and Spain (Cabrera et al 1982). $\alpha-\mathrm{GPDH}$ is monomorphic in most Drosophila species (Lakovaara and Keranen, 1980), although rare alleles in $D$. simulans, are known from Texas (Kojima et al., 1970), Hawaii (Steiner et al., 1976) and Greece (Triantaphyllidis et al., 1980).

Table 3 shows that, in most populations, about half of the 15 loci sampled were polymorphic with a mean of 2 alleles per locus and an average heterozygosity of 16 per cent. Differences between populations are generally small, although more 
Table 1 Frequency of alleles in populations of Drosophila simulans. Alleles marked * exhibit the same mobility as alleles found in D. melanogaster

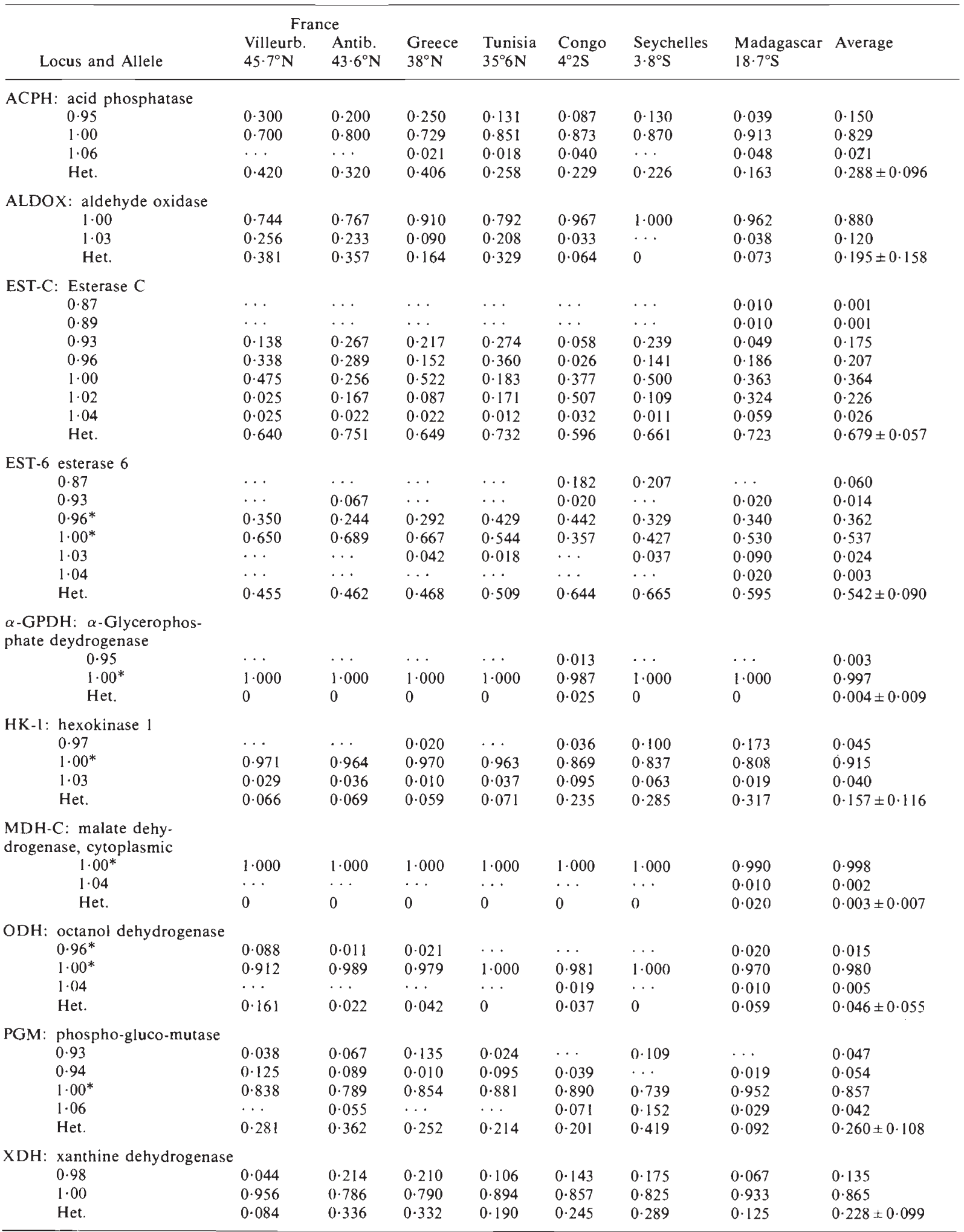


Table 2 Comparison of polymorphism within and hetween populations for polymorphic loci of $I$. simulans. Fixation index is $\mathrm{HT}-\overline{\mathrm{HS}} / \mathrm{HT}$; for 8 highly polymorphic loci. Chi square values and numbers of degrees of freedom (in brackets) are given (all values are statistically significant, $p<0.01$ )

\begin{tabular}{|c|c|c|c|c|}
\hline Loci & $\begin{array}{l}\text { Within } \\
\text { popul. } \\
\text { heteroz. } \\
\left(\bar{H}_{S}\right)\end{array}$ & $\begin{array}{l}\text { Total } \\
\text { heteroz. } \\
\left(H_{I}\right)\end{array}$ & $\begin{array}{l}\text { Fixation } \\
\text { index } \\
\left(\frac{H_{I}-\bar{H}_{S}}{H_{r}}\right)\end{array}$ & $\begin{array}{l}\text { Chi-square } \\
\text { (df) }\end{array}$ \\
\hline $\mathrm{ACPH}$ & $0 \cdot 288$ & $0 \cdot 302$ & $0 \cdot 043$ & $38 \cdot 9(6)$ \\
\hline ALDOX & 0.196 & 0.215 & 0.091 & $68 \cdot 1(6)$ \\
\hline EST-C & 0.684 & 0.754 & 0.094 & $214 \cdot 3(20)$ \\
\hline EST-6 & $0 \cdot 542$ & 0.569 & 0.048 & $116.4(13)$ \\
\hline$\alpha$-GPDH & 0.004 & $0 \cdot 004$ & 0 & - \\
\hline $\mathrm{HK}-1^{*}$ & 0.157 & $0 \cdot 165$ & 0.053 & $44 \cdot 33(3)$ \\
\hline $\mathrm{MDH}-\mathrm{c}$ & 0.003 & $0 \cdot 003$ & 0 & $-\ldots$ \\
\hline $\mathrm{OIOH}$ & 0.046 & $0 \cdot 047$ & 0.035 & $34 \cdot 7(6)$ \\
\hline PGM & $0 \cdot 260$ & 0.271 & 0.041 & $23 \cdot 5(6)$ \\
\hline $\mathrm{XDH}$ & 0.229 & $0 \cdot 236$ & 0.03 .3 & $20 \cdot 5(6)$ \\
\hline mean ( 10 polym. loci) & $0 \cdot 241$ & 0.253 & 0.046 & \\
\hline mean (all 15 loci) & $0 \cdot 161$ & 0.168 & 0.031 & \\
\hline
\end{tabular}

* Chi-square test done between the 4 temperate and the 3 tropical populations.

numerous alleles were found in two of the tropical populations from Congo and Madagascar.

Previously published estimates for heterozygosity of $D$. simulans range from $0 \cdot 059$ (Onishi et al., 1982) to 0.173 (Triantaphyllidis et al., 1980). However, these variations largely reflect differences in the number of loci sampled and the choice of loci and figures for the same locus studied by different authors, do not show great differences between populations. Although the proportion of polymorphic loci in one Japanese population (Onishi et al., 1982), is $0 \cdot 29$, all other observed values fall between 0.41 and 0.46 , not very different from 0.52 obtained by ourselves. The average number of alleles per locus varies from 1.46 (Cabrera et al., 1982) to 2.07 (Triantaphyllidis et al., 1980), thus including the value of $2 \cdot 00$ found here.

How much genetic divergence is there between geographically distant populations of the cosmopolitan specie D. simulans? An homogeneity
Chi-square test on the 8 highly polymorphic loci shows that there is a highly significant geographic heterogeneity (table 2). A more general method of comparing the total heterozygosity to within population heterozygosity is given by Wright's fixation index $F_{S T}$ (table 2). The observed values are generally low, with an average of 0.046 for the 10 polymorphic loci. As in D. melanogaster (Singh et al., 1982), $F_{S T}$ is not correlated with average heterozygosity.

Although there is significant heterogeneity among populations, there are no significant correlations between allele frequencies and latitude. Table 1 does suggest that there is a weak latitudinal trend for four loci. For ACPH ${ }^{0.95}$ and EST-6 ${ }^{1 \cdot 00}$, we note a decrease of allele toward the Equator. For ALDOX, the frequency of the 1.00 allele increases in tropical populations, and the $\mathrm{HK}-1$ polymorphism of the 4 temperate populations is significantly lower than is that of those in the

Table 3 Summary of allozyme polymorphism in various populations of Drosophila simulans

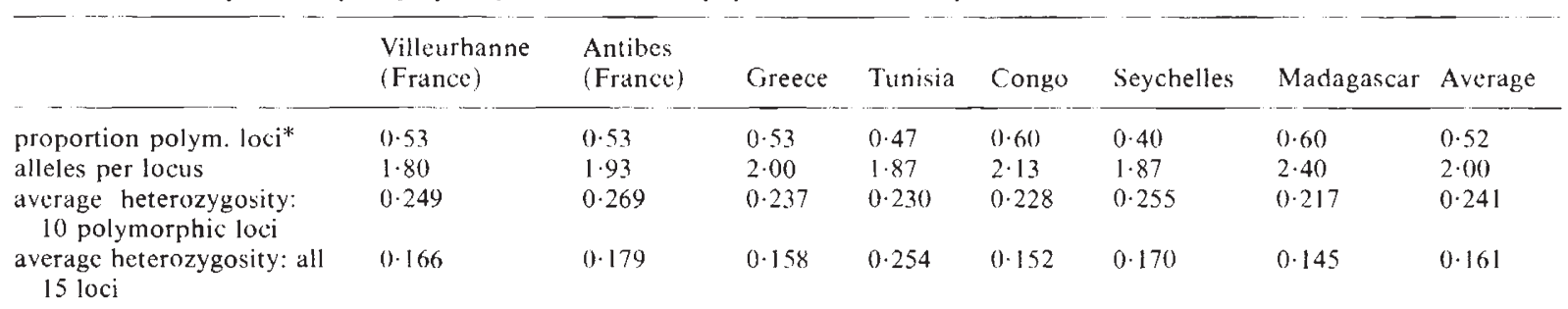

* Calculated at 1 per cent level. 
Table 4 Genetic identities (above diagonal) and genetic distances (below diagonal) between geographical populations of $D$. simulans

\begin{tabular}{llllllll}
\hline Populations & Anti. & Vill. & Gree. & Tuni. & Congo & Seych. \\
\hline Antibes & & 0.992 & 0.992 & 0.991 & 0.971 & 0.944 & Madag. \\
Villeurbanne & 0.008 & & 0.993 & 0.996 & 0.977 & 0.948 & 0.985 \\
Greece & 0.008 & 0.007 & & 0.988 & 0.980 & 0.955 & 0.987 \\
Tunisia & 0.009 & 0.004 & 0.012 & & 0.981 & 0.947 & 0.988 \\
Congo & 0.029 & 0.023 & 0.019 & 0.019 & & 0.954 & 0.963 \\
Seychelles & 0.057 & 0.054 & 0.046 & 0.054 & 0.048 & 0.037 & \\
Madagascar & 0.018 & 0.016 & 0.013 & 0.012 & 0.008 & \\
\hline
\end{tabular}

tropics. Finally, for PGM, an increase of heterozygosity with latitude is observed, if we exclude the very isolated Seychellian population. Similar latitudinal tendencies have already been noticed for 3 of these loci (EST-6, ACPH and PGM) in Greece over a much shorter geographic range by Triantaphyllidis et al., (1982) who did not study HK- 1 and ALDOX. In a survey of numerous populations from several continents, Anderson and Oakeshott (1984) found a latitudinal cline for EST-6 but did not find any significant variation for PGM. The problem of geographical trends in D. simulans loci will become clear only with the study of more populations for various parts of the world.

Genetic identities and genetic distances between populations were calculated according to Nei (1972) and are given in table 4. The distances ranged from 0.008 to 0.057 with an average of
$0 \cdot 024(n=21)$. Distances between the 4 temperate and the 3 tropical populations are significantly $(p<0.05)$ higher $(D=0.030+0.005 ; n=12)$ than between populations living under similar climatic conditions $(D=0 \cdot 016+0 \cdot 005 ; n=9)$. Tropical populations are more diverse and heterogeneous than the temperate ones. This could reflect their greater geographic distances. The Seychellian population, which is an isolated and small population with special ecological needs (David and Tsacas, unpublished) is the most different from all others (see also fig. 2).

\section{Quantitative data}

The results obtained for 9 French and 11 tropical African populations are given in table 5. For all biometrical traits (from fresh weight to ovariole number) the average values are lower in African

Table 5 Comparison of French and Afrotropical strains in Drosophila simulans and Drosophila melanogaster for various quantitative traits. Statistical significance: ${ }^{*}(p<0.05),{ }^{* *}(p<0.01)$

\begin{tabular}{|c|c|c|c|c|c|c|c|}
\hline \multirow[b]{2}{*}{ Traits } & \multirow[b]{2}{*}{ Sex } & \multicolumn{3}{|c|}{ D. simulans } & \multicolumn{3}{|c|}{ D. melanogaster } \\
\hline & & $\begin{array}{l}\text { France } \\
(n=9)\end{array}$ & $\begin{array}{l}\text { Trop. Africa } \\
(n=11)\end{array}$ & Difference & $\begin{array}{l}\text { France } \\
(n=30)\end{array}$ & $\begin{array}{l}\text { Trop. Africa } \\
(n=22)\end{array}$ & Difference \\
\hline $\begin{array}{l}\text { Fresh weight } \\
\left(\mathrm{mg}-10^{-2}\right)\end{array}$ & $\begin{array}{l}q \\
\delta\end{array}$ & $\begin{array}{r}109 \cdot 24 \pm 2 \cdot 17 \\
87 \cdot 32 \pm 1 \cdot 83\end{array}$ & $\begin{array}{l}93 \cdot 97 \pm 1 \cdot 16 \\
73 \cdot 63 \pm 1 \cdot 67\end{array}$ & $\begin{array}{l}15 \cdot 27 \pm 2 \cdot 33^{* *} \\
13 \cdot 69 \pm 9 \cdot 47^{* *}\end{array}$ & $\begin{array}{r}123 \cdot 22 \pm 0.81 \\
91 \cdot 91 \pm 0.73\end{array}$ & $\begin{array}{r}103 \cdot 37 \pm 1 \cdot 01 \\
78 \cdot 03 \pm 0 \cdot 94\end{array}$ & $\begin{array}{l}19 \cdot 85 \pm 1 \cdot 28^{* *} \\
13 \cdot 88 \pm 1 \cdot 17^{* *}\end{array}$ \\
\hline $\begin{array}{l}\text { Thorax length } \\
\left(\mathrm{mm}-10^{-2}\right)\end{array}$ & $\begin{array}{l}q \\
\delta\end{array}$ & $\begin{array}{r}105 \cdot 72 \pm 0.46 \\
94 \cdot 29 \pm 0 \cdot 63\end{array}$ & $\begin{array}{r}102 \cdot 04 \pm 0.62 \\
90 \cdot 39 \pm 0.64\end{array}$ & $\begin{array}{l}3 \cdot 68 \pm 0 \cdot 80^{* *} \\
3 \cdot 90 \pm 0 \cdot 90^{* *}\end{array}$ & $\begin{array}{r}107 \cdot 61 \pm 0 \cdot 37 \\
95 \cdot 23 \pm 0 \cdot 39\end{array}$ & $\begin{array}{r}102 \cdot 14 \pm 0.58 \\
88 \cdot 74 \pm 0.46\end{array}$ & $\begin{array}{l}2 \cdot 14 \pm 0.66^{* *} \\
6.49 \pm 0.60^{* *}\end{array}$ \\
\hline $\begin{array}{l}\text { Wing length } \\
\left(\mathrm{mm}-10^{-2}\right)\end{array}$ & $\begin{array}{l}q \\
\delta\end{array}$ & $\begin{array}{l}197 \cdot 29 \pm 1 \cdot 64 \\
173 \cdot 21 \pm 1 \cdot 24\end{array}$ & $\begin{array}{l}191 \cdot 23 \pm 2 \cdot 54 \\
168 \cdot 71 \pm 2 \cdot 11\end{array}$ & $\begin{array}{l}6 \cdot 06 \pm 3 \cdot 19^{*} \\
4 \cdot 50 \pm 2 \cdot 60^{*}\end{array}$ & $\begin{array}{l}227 \cdot 25 \pm 0 \cdot 77 \\
198 \cdot 06 \pm 0 \cdot 79\end{array}$ & $\begin{array}{l}206 \cdot 29 \pm 1 \cdot 14 \\
178 \cdot 80 \pm 0 \cdot 85\end{array}$ & $\begin{array}{l}20 \cdot 96 \pm 1 \cdot 32^{* *} \\
19 \cdot 26 \pm 1 \cdot 17^{* *}\end{array}$ \\
\hline $\begin{array}{l}\text { Sternopleural } \\
\text { chaetae } \\
\text { (number) }\end{array}$ & $\begin{array}{l}q \\
6\end{array}$ & $\begin{array}{l}21 \cdot 06 \pm 0 \cdot 24 \\
19 \cdot 34 \pm 0 \cdot 25\end{array}$ & $\begin{array}{l}19 \cdot 26 \pm 0.37 \\
17 \cdot 73 \pm 0.37\end{array}$ & $\begin{array}{l}1.80 \pm 0.46^{*} \\
1.61 \pm 0.46^{*}\end{array}$ & $\begin{array}{l}19 \cdot 57 \pm 0 \cdot 22 \\
18 \cdot 44 \pm 0 \cdot 22\end{array}$ & $\begin{array}{l}17 \cdot 41 \pm 0 \cdot 20 \\
16 \cdot 24 \pm 0 \cdot 21\end{array}$ & $\begin{array}{l}2 \cdot 16 \pm 0 \cdot 31^{* *} \\
2 \cdot 20 \pm 0 \cdot 32^{* *}\end{array}$ \\
\hline $\begin{array}{l}\text { Abdominal chaetae } \\
\text { (number) }\end{array}$ & $\begin{array}{l}q \\
0\end{array}$ & $\begin{array}{l}41 \cdot 37 \pm 0.68 \\
32 \cdot 45 \pm 0.60\end{array}$ & $\begin{array}{l}39: 10 \pm 0.68 \\
31 \cdot 77 \pm 0.62\end{array}$ & $\begin{array}{l}2.27 \pm 0.97^{*} \\
0.68 \pm 0.87\end{array}$ & $\begin{array}{l}43 \cdot 23 \pm 0 \cdot 29 \\
35 \cdot 47 \pm 0 \cdot 30\end{array}$ & $\begin{array}{l}39 \cdot 32 \pm 0 \cdot 46 \\
31 \cdot 42 \pm 0 \cdot 31\end{array}$ & $\begin{array}{l}3.91 \pm 0.52^{* * *} \\
4.05 \pm 0.44^{* *}\end{array}$ \\
\hline $\begin{array}{l}\text { Ovarioles } \\
\text { (number) }\end{array}$ & q & $37.96 \pm 0.94$ & $33 \cdot 13 \pm 0 \cdot 79$ & $4 \cdot 83 \pm 1 \cdot 21^{* *}$ & $47 \cdot 57 \pm 0 \cdot 45$ & $38 \cdot 59 \pm 0 \cdot 66$ & $8 \cdot 98 \pm 0 \cdot 74^{* *}$ \\
\hline $\begin{array}{l}\text { Development } \\
\text { (hours) }\end{array}$ & $\begin{array}{l}q \\
\delta\end{array}$ & $\begin{array}{l}199 \cdot 66 \pm 3 \cdot 93 \\
206 \cdot 26 \pm 3 \cdot 64\end{array}$ & $\begin{array}{l}205 \cdot 69 \pm 4 \cdot 05 \\
210 \cdot 72 \pm 3 \cdot 91\end{array}$ & $\begin{array}{l}-6 \cdot 03 \pm 6 \cdot 72 \\
-4 \cdot 46 \pm 5 \cdot 43\end{array}$ & $\begin{array}{l}208 \cdot 16 \pm 2 \cdot 06 \\
213 \cdot 22 \pm 2 \cdot 13\end{array}$ & $\begin{array}{l}207 \cdot 46 \pm 1 \cdot 75 \\
213 \cdot 27 \pm 1 \cdot 57\end{array}$ & $\begin{array}{r}0.70 \pm 2.84 \\
-0.05 \pm 7.28\end{array}$ \\
\hline Viability & $q+\delta$ & $73 \cdot 97 \pm 4 \cdot 80$ & $70 \cdot 97 \pm 2 \cdot 85$ & $3 \cdot 00 \pm 5 \cdot 35$ & $73 \cdot 43 \pm 2 \cdot 24$ & $67 \cdot 60 \pm 2 \cdot 61$ & $5 \cdot 83 \pm 3 \cdot 44$ \\
\hline
\end{tabular}


than in European strains and, among 11 calculated differences, 8 are significant at the 0.05 level. These results are similar to those already obtained in $D$. melanogaster (Table 5 and David et al. 1977).

Viability and duration of development show only small and non significant differences between French and African strains; in D. melanogaster also these physiological traits do not discriminate between tropical and temperate populations.

The contrast between temperate and tropical strains of $D$. simulans can be illustrated by a principal components analysis (fig. 1) on 5 biometrical traits available for both sexes (weight, wing and

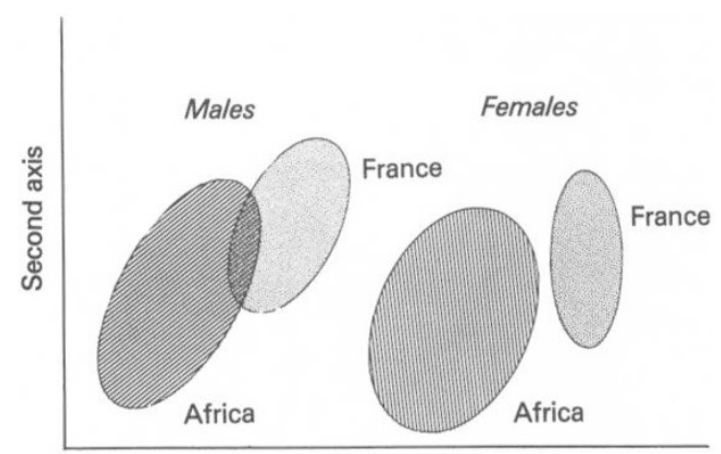

First axis

Figure 1 Result of a principal components analysis applied to 5 biometrical traits of French and Afrotropical strains of Drosophila simulans. Each ellipse is calculated for including 75 per dent of strains. The two tirst axes restitute 92 per cent of the total information.

thorax lengths and chaetae numbers). The two first axes constitute 92 per cent of the total variation. The first is mainly correlated to length characters (thorax and wing) and the second to chaetae numbers. Males are clearly separated from females because of their small size and geographic discrimination is better for females than for males.

\section{DISCUSSION}

How much polymorphism and geographic differentiation is there in D. simulans and how do these data compare to those already obtained from its sibling cosmopolitan species $D$. melanogaster?

Published results on allozyme polymorphism for $D$. simulans are quite diverse. The level of heterozygosity is strongly influenced by the choice of loci and by the number of loci studied. However, if we average the values of Kojima et al., (1970), Steiner et al., (1976), Triantaphyllidis et al., (1980), Cabrera et al., (1982), Onishi et al., (1982) and ourselves, we obtain a mean of 0.12 ; a proportion of polymorphic loci of 0.44 ; and an estimate of mean number of alleles per locus of $1 \cdot 8$. These estimates, albeit imprecise are comparable to those found in other organisms (Powell, 1975; Nevo, 1978). D. simulans is less variable than are some tropical Drosophila species but is not very different in this respect from the average Drosophila. An average of these parameters in $D$. melanogaster using the studies of Kojima et al., (1970), Langley et al., (1974), Band (1975), Triantaphyllidis et al., (1980), Cabrera et al., (1982), Onishi et al., (1982), Singh et al., (1982), provides an estimate of 0.15 for $\bar{H}$, of 0.65 for proportion of polymorphic loci, and of 1.8 for the number of alleles per locus. Although these comparisons should be extended to more loci studied with identical techniques in the same laboratory, it does seem that while $D$. melanogaster may have a slightly elevated heterozygosity and a greater proportion of polymorphic loci, neither of the two sibling species are exceptional in this respect within the genus Drosophila. If we extend the comparison to single loci, we find that while $D$. simulans is monomorphic or almost monomorphic for loci which are highly polymorphic in D. melanogaster (such as ADH, $\alpha-\mathrm{GPDH}$ and G6PD) several loci (such as EST-C and $\mathrm{ACPH}$ ) are more variable in $D$. simulans.

ACPH, ALDOX, EST-6 and HK-1 in D. simulans do apparently show some tendency to vary with latitude (although this work needs to be extended by the study of more populations on different continents) and only the EST-6 (Anderson and Oakeshott, 1984) data are at all satisfactory. Genetic distances are smaller between populations living in the same geographic area with the extension of the isolated Seychelles population.

There is a clear contrast between $D$. melanogaster and D. simulans: D. simulans is far less geographically diversified than is its sibling. Although it is difficult to compare "D" in 2 species with different sets of loci and different geographical patterns of sampling, the average value of $D$ in $D$. simulans is about 4 times lower than in D. melanogaster (Singh et al., 1982) (see fig. 2). The genes studied in D. simulans are a subset of those studied in D. melanogaster and its populations were sampled from much less diverse places. However, the lower variability of $D$. simulans is confirmed even if we consider only the case of single loci and examine the values of their fixation index. In D. melanogaster, 17 loci out of 25 had values superior to 0.1 and the average was 0.164 (Singh et al., 1982). In D. simulans no fixation 


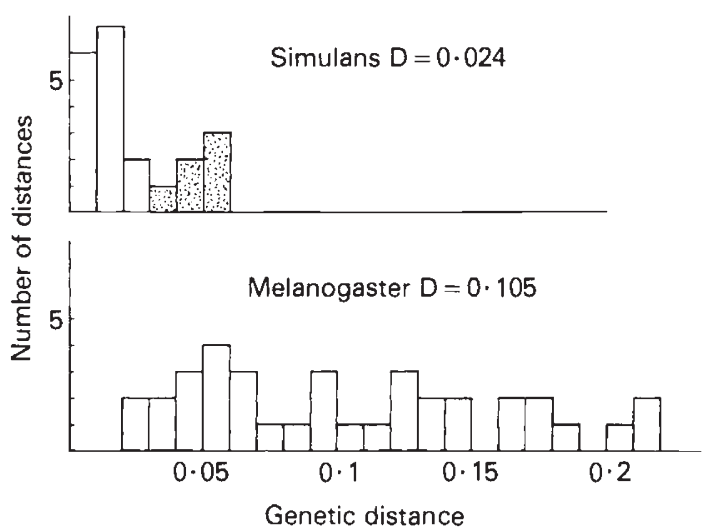

Figure 2 Distribution of genetic distances calculated between geographic populations of $D$. simulans (this work) and $D$. melanogaster (after Singh et al., 1982). D: average value of genetic distance. For $D$. simulans, dotted values correspond to distances including the Seychelles population.

index has a value superior to $0 \cdot 1$ and the average over 10 polymorphic loci gives a value of 0.046 . In $D$. melanogaster, the greatest genetic contrast is between Afrotropical and temperate populations (David, 1982; Singh et al., 1982) and nothing analogous exists in $D$. simulans, in spite of the fact that Afrotropical populations are probably ancestral in both species.

There is an increase in average values of morphological traits in European populations of D. simulans. The changes concern fresh weight, thorax length, sternopleural and abdominal chaetae numbers, and ovarioles in females, and are similar to those of $D$. melanogaster (table 5). This evolutionary parallelism is illustrated by a discriminant analysis of 6 morphological traits of females (fig. 3).

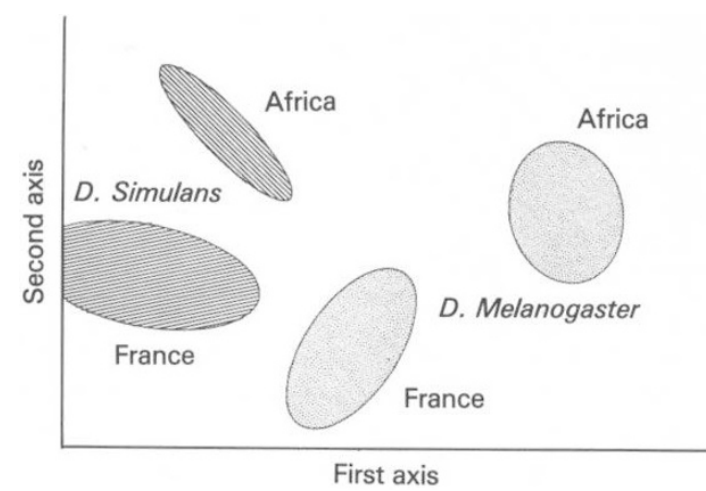

Figure 3 Result of a discriminant analysis applied to 6 biometrical traits of females of $D$. melanogaster and $D$. simulans. Each ellipse includes 75 per cent of strains. The two first axes restitute 99 per cent of the total information.
A direct comparison of phenotypic divergence in the two species is not possible since $D$. simulans is smaller than $D$. melanogaster. We use a relative measure: for each trait, each sex and each species the ratio of the difference to the average value of the trait in French and African populations is calculated. This index is superior for $D$. melanogaster in 10 out of 11 cases. The only exception concerns male weight for which the changes are almost identical in the two species. If we compare these proportions by a simple statistical test, for example Chi square, we get a value of $7 \cdot 36$ with 1 degree of freedom $(p<0.01)$. We can conclude that for morphology, $D$. simulans is less geographically variable than is $D$. melanogaster, although the contrast is less pronounced than for allozymes.

D. simulans is monomorphic for chromosome structure, does not exhibit a latitudinal cline for ethanol tolerance and is less variable than $D$. melanogaster for its protein polymorphism measured by 2-dimensional gel electrophoresis. However, there do exist parallel latitudinal clines in the two species in Australia for tolerance to desiccation (Parsons, 1980b,c), and D. simulans from Africa appears to differ from European populations in the composition of cuticular hydrocarbons (Luyten, 1982). In addition pattern of change in mitochondrial DNA suggests that $D$. simulans is divided into three geographic groups, one found in Madagascar, a second in Seychelles, New Caledonia and Hawaii, and a third in the rest of the world (Baba-Aissa and Solignac, 1984).

It was expected 20 years ago (Baker and Stebbins, 1965) that there may be some common genetic properties of colonising species. Our results show that this suggestion is far from true. $D$. simulans and $D$. melanogaster are closely related and are the most efficient colonisers in the genus Drosophila. However, the genetic structures of geographic populations are different; for most traits, (including protein polymorphism, chromosome structure, alcohol tolerance and morphology) $D$. simulans is much less differentiated than is $D$. melanogaster. It is not yet known whether the two species do show geographical parallelism in other traits which might result from the action of natural selection.
Acknowledgments We are grateful to Drs D. Lachaise, B. Pintureau, S. Tsakas and J. Vouidibio for providing some $D$. simulans populations as well as to Mrs De ScheemackerLouis and E. Pla for doing the biometrical measurements. 


\section{REFERENCES}

ALIEMAND, R. AND I)AVID, J. R. 1976. The circadian rhythm of oviposition in Drosophila melanogaster: A genetic latitudinal cline in wild populations. Experientia, 32, 1403 1404.

ANDERSON, P. R. AND OAKISSHOTT, J. C., 1984. Parallel geographical pattern of allozyme variation in two sibling Drosophila species. Nature, 308, 729-731.

ASHBURNER, M. ANI) LEMEUNIER, F. 1976. Relationship within the melanogaster species subgroup of the genus Drosophila (Sophophora). I. Inversion polymorphisms in Drosophila melanogaster and D. simulans. Proc. $R$. Soc. Lond. B, 193, 137-159.

AYALA, F. J., POWELI, R, TRACEY, M. L., MOURA, $\therefore$ A. AND PERI:Z-SALAS, S. 1972. Enzyme variability on the $D$. willis toni group. IV. Genic variation in natural populations of D. willistoni. Genetics, 7l, 113-139.

BABA-AISSA, F. ANI) SOLIGNAC, M. 1984. La plupart des populations actulles de Drosophila simulans ont probablement pour ancêtre une femelle unique dans un passé récent. C.R. Acad. Sci. Paris. 299, 289-292.

BAKER, H. G. AND STEBBINS, G. L. 1965. The genetics of colonizing species. New York, Acad. Press, 588 pp.

BAND, H. T. 1975. A survey of isozyme polymorphism in a Drosophila melanogaster natural populations. Genetics, 80 , $761-771$.

BERGER, E. M. 1970. A comparison of gene-enzyme variation between Drosophila melanogaster and $D$. simulans. Genetics, 66, 677-683.

BOULETREAU-MERLE, 3, ALI.EMAND, R, (OHET Y. AND) DAVID, J. R. 1982. Reproductive strategy in Drosophila melanogaster: significance of a genetic divergence between temperate and tropical populations. Oecologia, 53, 323-324.

CABRERA, V. M., GONZALFZ, A. M, LARRAGA, J. M. AND GULLON, A. 1982. Electrophoretic variability in natural populations of Drosophila melanogaster and D. simulans. Genetica, 59, 191-201.

CAPY, P., DAVID, J. R, ALLEMANI, R., HYYTIA, P. AND ROUAult, J. 1983. Genetic properties of North African Drosophila melanogaster and comparison with European and Afrotropical populations. Genet. Sel. Evol., 15 (2), $185-200$

COHET, Y., VOUIDIBIO, J. AND DAVII), J. R. 1980. Thermal tolerance and geographic distribution: a comparison of cosmopolitan and tropical endemic Drosophila species. J. Therm. Biol., 5, 69-74.

DAVII), J. R. 1974. Utilization of morphological traits for the analysis of genetic variability in wild populations. Aquilo, Ser. Zool., 20, 49-61.

DAVID, J. R. 1982. Latitudinal variability of Drosophila melanogaster: Allozyme frequencies divergence between European and Afrotropical populations. Biochemical Genetics, 20,7/8, 747-761.

DAVID, J.R. ANI) BOCOUET, $($. 1975. Similarities and differences in latitudinal adaptation of two Drosophila sibling species. Nature, 257, 588-590.

DAVII), J. R., BOCQUFT, C. AND PI.A, F. 1976. New results on the genetic characteristics of the Far East race of Drosophila melanogaster. Genet. Res. Camb., 28, 253-260.

DAVID, J. R., BOCQUET, C. ANI DI: SCHEEMAI:KI:R-LOUIS, M 1977. Genetic latitudinal adaptation of Drosophila melanogaster: New discriminative biometrical traits between European and Equatorial African populations. Genet. Res. Camb., 30, 247-255.

DAVID, J. R. AND TSACAS, L. 1981. Cosmopolitan, subcosmopolitan and widespread species: Different strategies within the Drosophilid family (Diptera). C.R. Soc. biogeog. $57,11-26$.

KimURA, M. 1983. The Neutral Theory of Molecular Evolution. Cambridge Univ. Press, Cambr., 367 pp.

KNHBB, W. R. 1982. Chromosome inversion polymorphisms in Drosophila melanogaster. II. Geographic clines and climatic associations in Australasia, North America and Asia. Genetica, 58, 213-221.

KNIBB, W. R., OAKESHOTT, J. I. AND GIBSON, J. R. 1981 Chromosome inversion polymorphism in Drosophila melanogaster. I. Latitudinal clines and associations between inversions in Australian populations. Genetics, 98 $833-847$

KOJIMA, K. I., (;ILLESPIE, J. AND) TOBARI, Y. N. 1970. A profile of Drosophila species enzymes assayed by electrophoresis. I. Number of alleles, heterozygosities, and linkage disequilibrium in Glucose-metabolizing systems and some other enzymes. Biochem. Genet., 4, 627-637.

I.AKOVAARA. S. AND KERANEN, L. 1980. Variation at the $\alpha$-gpdh locus of Drosophilids. Hereditas, 92, 251-258.

LAN(jLEY, C. H., TOBARI, Y. N. ANI) KOJIMA, K. I. 1974. Linkage disequilibrium in natural populations of Drosophila melanogaster. Genetics, 78, 921-936.

LEWONTIN, R. C. 1984. Detecting population differences in quantitative characters as opposed to gene frequencies. Amer. Nat., 123, 115-124.

LUYTIN, I. 1982. Variations intraspécifique et interspécifique des hydrocarbures cuticulaires chez Drosophila simulans et des espèces affines. C.R. Acad. Sci. Paris, 295, 733-736.

MEITLER, I. E., VOELKER, R. A. ANI) MUKAI, T. 1977. Inversion clines in populations of Drosophila melanogaster. Genetics, $87,169-176$

NEI, M. 1972. Genetic distance between populations. Am. Nat., $106,283-290$

NEV(), E. 1978. Genetic variation in natural populations: patterns and theory. Theoret. Pop. Biol., 13, 121-177

OAKESHOTT, J. G., CHAMBER., G. K., GIBSON, J. B. AND WIL.LCOKS, D. A. $1981 a$. Latitudinal relationship of esterase-6 and phosphoglucomutase gene frequencies in Drosophila melanogaster. Heredity, 47 (3), 385-396.

OAKESHOTT, J. (j., GIBSON, J. B., ANDERSON, P. R., KNIBB, W. R., ANDERSON, D. G. ANI) CHAMBERS, (. K. 1981 b. Alcohol dehydrogenase and Glycerol-3 phosphate dehydrogenase clines in Drosophila melanogaster on different continents. Evolution, 36 (1), 86-96.

O'BRIEN, S. I. ANI) MACINTYRE, R. J. 1969. An analysis of gene-enzyme variability in natural populations of Drosophila melanogaster and D. simulans. Am. Nat., 103, 97-113.

ONISHI, S., LEIGH BROWN, A. 3., VOILLKER, R. A. AND LANGLEY, (. H. 1982. Estimation of genetic variability in natural populations of $I$ ). simulans by two dimensional and starch gel electrophoresis. Genetics, 100, 127-136.

PARSONS, P. A. 1975. The comparative evolutionary biology of the sibling species. Drosophila melanogaster and $D$. simulans. Quat. Rev. Biol., 50, 151-169.

PARSONS, P. A. 1980a. Isofemale strains and evolutionary strategies in natural populations. Evolutionary Biology, 13, $175-217$

PARSONS. P. A. 1980 b. Parallel climatic races for tolerances to high temperature desiccation stress in two Drosophila species. J. Biogeog., 7, 97-101.

PARSONS, P. A. 1980 c. Adaptative strategies in natural populations of Drosophila: Ethanol tolerance, desiccation resistance and development times in climatically optimal and extreme environments. Theor. Appl. Genet., 57, 257-266.

PARSONS, P. A. 1983. The Evolutionary Biology of Colonizing Species. Cambridge Univ. Press, Cambridge, $262 \mathrm{pp}$ 
PARSONS, P. A. AND STANLEY, S. M. 1981. Domesticated and widespread species. Ashburner, M., Carson, H. L. and Thompson, J. N. Jr., (eds.) The Genetics and Biology of Drosophila, Vol. 3a, Acad. Press, New York, pp. 349-393.

POWELL, J. R. 1975. Protein variation in natural populations of animals. Evolut. Biol., 8, 79-119.

SALAM, E. A., EL-ADL, A. M. AND KOSBA, Z. A. 1981. Isozyme polymorphism in Drosophila. IV. Interspecific variation and population dynamics. Proc. 7th Europ. Drosoph. Conf., Oulu-Finland, pp. 227-235.

SHOW, C. R. AND PRASAD, R. 1970. Starch gel-electrophoresis of enzymes, A compilation of recipes. Biochem. Genet., 4, 297-320.

SINGH, R. A., HICKEY, D. A. AND DAVID, J. R. 1982. Genetic differentiation between geographically distant populations of Drosophila melanogaster. Genetics, 101, 235-256.

STALKER, H. D. 1980. Chromosome studies on wild populations of Drosophila melanogaster. II. Relationship of inversion frequencies to latitude, season, wing-loading and flight activity. Genetics, 95, 211-223.

STEINER, W. W., SANY, K. L. AND PAIK, Y. 1976. Electrophoretic variability in island population of Drosophila simulans and D. immigrans. Biochem. Genet., 14, 495-506.

TANTAWY, A. O. ANI MALLAH, G. S. 1961. Studies on natural populations of Drosophila. 1. Heat resistance and geographic variation Drosophila melanogaster and D. simulans. Evolution, 15, 1-14.

TEISSIER, G. 1957. Discriminative biometrical characters in French and Japanese Drosophila melanogaster. Proc. Int. Genet. Symp. Tokyo-Kyoto. 1956. Cytologia suppl., 502505
TRIANTAPHYLLIDIS, C. D. 1973. Allozyme variation in populations of Drosophila melanogaster and $D$. simulans from Northern Greece. J. Heredity, 64, 69-72.

TRIANTAPHYLLIIDIS, C. D., SCOURAS, Z. G., PANOURGIAS, J. N. ANI) IOANNIDIS, G. C. 1982. Allozyme variation in Greek wild populations of Drosophila melanogaster and D. simulans along a North-South gradient. Genetica, 58, 129-136.

TRIANTAPHYLLIDIS, C. I)., PANOURGIAS, J. N., SCOURAS, J. G. AND IOANNIDIS, G. C. 1980. A comparison of geneenzyme variation between Drosophila melanogaster and Drosophila simulans. Genetica, 51, 227-231.

TSACAS, L. AND LACHAISE, D. 1974. Quatre nouvelles espèces de la Côte-d'Ivoire du genre Drosophila, groupe Melanogaster et discussion de l'origine du sous-groupe melanogaster (Diptera; Drosophilidae). Ann. Univ. Abidjan, Ser. E. (Ecol.), 7, 193-211.

VOELKER, R. A., COCKERHAM, C. C., JOHNSON, F. M., SCHAFFER, H. E., MUKAI, T. ANID METTLER, L. E. 1978. Inversions fail to account for allozyme clines. Genetics, 88, 515-527.

VOELKER, R. A., MUKAI, T. AND JOHNSON, F. M. 1977. Genetic variation in populations of Drosophila melanogaster from the Western United States. Genetica, 47, 143-148.

WATANABE, T. K. AND WATANABE, T. 1977. Enzyme and chromosome polymorphism in Japanese natural populations of Drosophila melanogaster. Genetics, 85, 319-329.

WHEELER, M. R. 1981. The drosophilidae: a taxonomic overview. Ashburner, M., Carson, H. L. and Thompson, J. N. Jr. (eds.) The Genetics and Biology of Drosophila, Vol. 3a, Academic Press, New York, pp. 1-121. 